\title{
PERMODALAN PADA USAHA KECIL MENENGAH SARUNG TENUN DI DESA WEDANI KECAMATAN CERME KABUPATEN GRESIK
}

\section{Noviyana Syafa'atin Magfiroh}

Program Studi Manajemen

Fakultas Ekonomi dan Bisnis

Universitas Muhammadiyah Gresik

Jln. Sumatra 101 GKB Gresik

\section{ABSTRAK}

Tujuan dari penelitian ini adalah untuk menganalisis permodalan pada UKM sarung tenun di Desa Wedani Kecamatan Cerme Kabupaten Gresik. Penelitian ini merupakan jenis penelitian kualitatif dengan pengumpulan data menggunakan tehnik interview. Kesimpulan yang didapat dari hasil penelitan ini adalah bahwa modal sendiri berpengaruh dengan tingkat pengembalian modal dan modal sendiri (equity) berhubungan dengan tingkat pengembalian modal sendiri yang di perkuat dengan kas (liquiditas).

\section{Keywords: Modal, Modal Sendiri, Liquiditas, Equity}

\section{PENDAHULUAN}

Tantangan yang dihadapi para pelaku usaha semakin beragam pada saat ini persaingan bisnis yang semakin kompleks dan kompetitif adalah salah satunya strategi yang diterapkan oleh pemerintah Indonesia adalah penguatan kemandirian lokal, maksudnya adalah fokus pengembangan perekonomian lebih diarahkan pada pencapaian kemandirian ekonomi internal. Implementasi strategi tersebut olehpemerintah direalisasikan dengan fokus penguatan dan pengembangan Usaha Mikro Kecil Menengah (UMKM).Berikut data perkembangan UMKM di JawaTimur priode 2013-2015

Tabel 1: Perkembangan UMKM di JawaTimur Periode 2013-2015

\begin{tabular}{|c|c|c|c|}
\hline Uraian & 2013 & 2014 & 2015 \\
\hline Unit Usaha (unit) & 803.45 & 807.4 & 807.903 \\
\hline Industri Kecil & 785.906 & 789.837 & 789.957 \\
\hline IndustriMenengah & 16.484 & 16.566 & 16.863 \\
\hline IndustriBesar & 1.064 & 1.075 & 1.083 \\
\hline $\begin{array}{l}\text { TenagaKerja } \\
\text { (orang) }\end{array}$ & 3.115 .681 & 3.133 .049 & $\begin{array}{r}3.134 .80 \\
9 \\
\end{array}$ \\
\hline Industri Kecil & 1.806 .045 & 1.815 .076 & 1.815 .57 \\
\hline IndustriMenengah & 951.666 & 956.424 & 956.888 \\
\hline IndustriBesar & 357.970 & 361.549 & 362.347 \\
\hline
\end{tabular}

Tabel perkembangan UMKM di jawa timur periode 2013 - 2015 membuktikan bahwa sektor UMKM memiliki peran strategis bagi perekonmian di jawa timur. Berdasarkan data Kementerian Koperasi dan Usaha Kecil Menengah (KUKM) kontribusi sektor UMKM terhadap Produk Domestik Bruto (PDB) meningkat dari 57,84\% menjadi 60,34 \% (Muthmainnah, 2016). Peningkatan ini tercatat selam lima tahun terakhir.Penguatan sektor UMKM dapat menimbulkan dampak positif bagi pertumbuhan perekonomian seperti terbukanya lapangan pekerjaan, peningkatan ekonomi lokal, penanggulangan kemiskinandan sebagainya.

Untuk mendukung penguatan UMKM, pemerintah telah melakukan berbagai upaya melalui perumusan dan pemberlakuan kebijakan.Salah satu contoh nyata dari langkah pemerintah adalah peluncuran paket kebijakan ekonomi. Dalam paket kebijakan ekonomi yang telah diumumkan pada 2016 lalu, salah satu unsur kebijakan yang pro UMKM adalah rendahnya tingkat suku bunga untuk Kredit Usaha Rakyat Berorientasi Ekspor (KURBE) (Paket Kebijakan Ekonomi Jilid 11, 2016). Paket kebijakan ini banyak dimanfaatkan UMKM untuk memperoleh pendanaan dengan bunga yang terjangkau.

Paket Kebijakan Ekonomi sangat membantu UMKM dalam mencukupi kebutuhan 
dananya, sepertihalnya di kota Gresik yang dikenal kaya akan industri, hingga dikatakan sebagai kota industri. Data Badan Pusat Statistik (BPS) tahun 2013 terdapat kurang lebih sekitar 402 Perusahaan di kota Gresik di berbagai Kecamatan.Selain perusahaan skala besar dan sedang, UMKM juga turut meramaikan dunia usaha di kota Gresik.Di kota Gresik terdapat kurang lebih 184.816 UMKM, koperasi kuranglebih 1.026, sentra UMKM ada 23 sentra dan Sentra Industir Kecil dan Menengah kuranglebih 112 Sentra(Najikh, 2015).

Kabupaten gresik terkenal dengan kota industri karena jumlah industri, baik industri kecil, menengah maupun besar yang lebih banyak dibandingkan dengan kabupaten di sekitarnya. Tercatat di Dinas Koperasi Perindustrian dan Perdagangan (DISKOPERINDAG). Berikut4 kecamatan dengan jumlah UMKM terbanyak :

\section{Jumlah Industri Kabupaten Gresik}

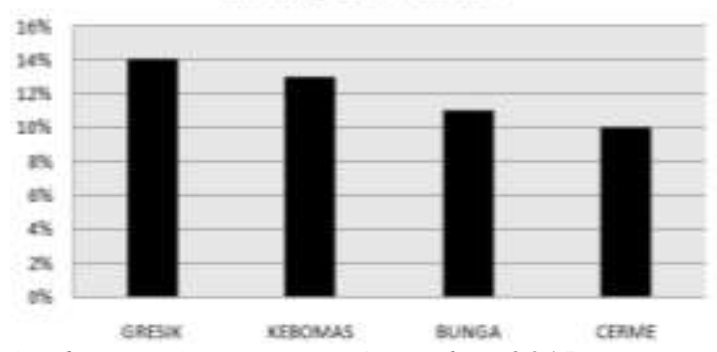

Sumber: DISKOPERINDAG Tahun 2015

Gambar 1:Jumlah industri di kabupaten Gresik

Dari ke empat kecamatan di kabupaten Gresik dengan presentase jumlah UMKM terbanyak, terdapat kecamatan dengan UMKM yang memiliki produk dengan nilai jual cukup tinggi dan merupakan kluster produk terbayak di kabupaten gresik, yaitu kecamatan cerme. Produk UMKM di kecamatan cerme dengan nilai jual yang cukup tinggi yaitu Sarung Tenun Alat Tenun Bukan Mesin (ATBM). Kluster Sarung Tenun Alat Tenun Bukan Mesin (ATBM) yang merupakan kluster produk terbanyak sesuai dengan data yang di peroleh dari Dinas Koperas Perindustrian dan Perdagangan (DIKOPERINDAG), yaitu, kluster sarung tenun sebanyak 23, kemudian perdagangan sebanyak
13, kluster kerajinan sebanyak 10, kluster jasa sebanyak 9, kluster olahan makanan ringan sebanyak 5, kluster makanan dan minuman sebanyak 5, kluster perikanan sebanyak 3 dan kluster yang paling rendah yakni kluster batik dengan jumlah 2.

Sarung tenun ATBM (Alat Tenun Bukan Mesin) yang berpusat di desa Wedani Kecamatan Cerme. Berikut Data jumlah ukm sarung tenun ATBM di desa wedani cerme :

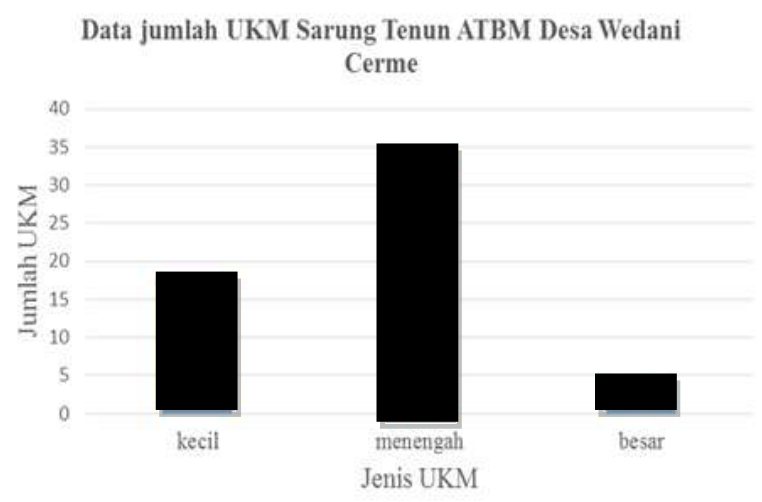

Sumber: Profil DesaWedani 2015

Gambar 2: Data jumlah UKM Sarung Tenun Desa Wedani Cerme

Menurut Bapak Bambang Supeno selaku kepala bagian ekonomi dan pembangunan Desa Wedani bahwa UKM sarung tenun ATBM merupakan UKM binaan PT. Telkom Indonesia.Usaha ini berdiri pada tahun 2009 sampai sekarang. PT. Telkom Indonesia pada tahun 2009 berperan sebagai pemberi bantuan modal usaha, akan tetapi bantuan modal tersebut hanya sampai akhir masa jabatan Kepala Desapada tahun 2009. Pada awal perkembangannya yakni pada tahun 2009 hingga awal tahun 2011, sarung tenun ATBM ini mampubersaing di wilayah regional. Bahkan pada tahun 2011sarungtenun ATBM merambah pasar di luar Jawa Timur seperti Sampang, Pamekasan dan Bangkalan.

Bapak Bambang juga menyatakan bahwa Mata pencaharian penduduk DesaWedani pada saat itu menggantungkan pada usaha tenun ATBM untuk membantu perekonomian di desa tersebut. Sebagian besar masyarakat desa berprofesi sebagai pengrajin sarung 
tenun.Hampir di setiap rumah, produksi sarung tenun dikerjakan. Permintaan produk sarung tenun ATBM yang terus meningkat pada saat itu membuat para pengrajin mempekerjakan tenaga kerja dari luar daerah tersebut.Sarung tenun yang diproduksi berbahan dasar kain sutra dengan motif yang beragam. Pada tahun 2014, usaha sarung tenun ATBM ini mengalami penurunan kapasitas produksi. Penurunan ini masih terus terjadi hingga saat ini. Satu minggu tercatat kurang lebih hanya tiga sarung tenun yang dapat dihasilkan.

Penurunan kapasitas produksi ini disebabkan karena minimnya modal usaha.Imbasnya adalah para pelaku pengrajin tenun tidak mampu untuk membeli bahan baku yang dibutuhkan. Saat ini sekitar $70 \%$ pengrajin tenun yang masih bertahan. Sisanya yakni sebesar $30 \%$ memilih beralih profesi di bidang lain.Pelaku UMKM cenderung menghindari pendanaan dari utang karena resikonya yang tinggi.Begitulah pandangan pelaku UKM terkait penggunaan hutang dalam komposisi modal pada UKM sarung tenun ATBM Desa Wedani Kecamatan Cerme.

Pelaku UKM perlu memiliki kemampuan manajerial permodalan yang baik.Penentuan sumber dana yang digunakan harus didasarkan pada pertimbangan yang memadai. Sumber pendanaan kegiatan usaha dapat diperoleh dari dua sumber, yakni hutang dan modal sendiri (Nugroho, 2010).Untuk memutuskan besarnya porsi pendanaan dari hutang maupun modal sendiri diperlukan pengetahuan terkait manajemen permodalan dan konsekuensi atas pemilihan setiap alternatif.Penelitian terkait struktur modal telah banyak dilakukan,Afifah dan Setiawan (2012) menemukan bantuan kredit dari Diskoperindag kota Semarang dapat meningkatkan modal usaha, omzet penjualan dan laba para pelaku usaha mikro di Kelurahan Pekunden.

Berdasarkan uraian yang telah disebutkan di atas, serta masih minimnya penelitian yang membahas tentang permodalan UMKM secara mendalam dengan metode kualitatif, peneliti tertatik untuk melakukan penelitian tentang
Permodalan UMKM Studi Kasus Pada UMKM Sarung Tenun ATBM Desa Wedani Kecamatan Cerme Kabupaten Gresik.

\section{TINJAUAN PUSTAKA \\ Teori Pecking Order}

Teoripecking Oreder menyatakan bahwa perusahaan lebih suka menggunakan pendanaan internal dibandingkan pendanaan eksternal, hutang yang aman dibandingkan hutang yang beresiko serta yang terakhir adalah saham biasa (Myers,1984). pecking order theory mengasumsikan bahwa perusahaan bertujuan untuk memaksimumkan kesejahteraan pemegang saham. Apabila diperlukan pendanaan dari eksternal maka perusahaan akan menerbitkan sekuritas paling aman terlebih dahulu yaitu dimulai dengan penerbitan obligasi, kemudian diikuti oleh sekuritas yang berkarasteristik opsi, baru akhirnya apabila masih belum mencukupi akan menerbitkan saham baru. Jadi urutan penggunaan sumber pendanaan dengan pengacu pada pecking order theory adalah internal fund (dana internal), debt (hutang) danequity (ekuitas).

$$
\text { Dikemukakan oleh myers }
$$

menggunakan dasar pemikirana bahwa tidak ada satu target debt to equity ratio tertentu dimana hanya ada tentang hirarkisumberdana yang paling disukai oleh perusahaan. Teori ini menjelaskan mengapa perusahaan yang profitable umumnya menggunakan hutang dalam jumlah yang sedikit. Hal tersebut bukan disebabkan karena perusahaaan mempunyai target debt ratio yang rendah, tetapi karena mereka memerlukanexternal financing yang sedikit. Perusahaan yang kurang profitable akan cenderung menggunakan hutang yang leih besarkarena dua alasan, yaitu; (1)dana internal tidak mencukupi, dan (2) utang merupakan sumber eksternal yang lebih disukai. Hal ini lah yang membutuhkan peratian dan analisis yang mendalam dalam mengambil suatu keputusan bijaksana.

Sumber pendanaan ini digolongkan menjadi modal sendiri dan sumber dana pinjaman.modal sendiriadalahsumberdana yang berasaldaripemilikperusahaan. Sumber dana 
pinjaman adalah sumber dana yang berasal dari luar kegiatan operasiaonal perusahaan seperti hutang kepada kreditur.

Sruktur modal yang optimal adalah sruktur modal yang mengoptimalkan keseimbangan antara resiko dan pengembalian.

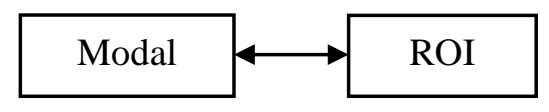

Gambar 3:Prespektif Teoritis

\section{METODE PENELITIAN}

Jenis penelitian tentang Permodalan UKM Sarung Tenun ATBM Di Desa Wedani Kecamatan Cerme ini merupakan jenis penelitian kualitiatif. Moloeng (2014 : 6) berpendapat bahwa penelitian kualitatif adalah penelitian yang bermaksud untuk memahami fenomena tentang apa yang dialami oleh subjek penelitian dengan cara deskripsi dalam bentuk kata-kata dan bahasa, pada suatu konteks khusus yang alamiah dengan memanfaatkan berbagai metode ilmiah. Penelitian ini menggunakan paradigma interpretif. Paradigma interpretif digunakan karena peneliti ingin mempelajari dan memahami fenomena yang akan diteliti, yaitu makna praktik permodalan bagi UMKM. Sesuai dengan yang dikatakan oleh Chua dalam Kamayanti (2016) bahwa paradigma interpretif berakar dari filsuf Jerman yang menekankan bahasa, interpretasi, dan pemahaman dalam ilmu sosial.

\section{Pendekatan Penelitian}

Dalam penelitian ini, pendekatan yang digunakan adalah studi kasus. Studi kasus adalah pendekatan atau strategi yang "focuses on understanding the dynamics present within single settings" (Huberman dan Miles dalam Kamayanti, 2016 : 75). Dengan kata lain, pendektan studi kasus berfokus untuk memahami dinamika terkait kondisi terkini pada suatu setting tertentu. Secara spesifik, kata "kasus" merujuk pada individu, kelompok, institusi, komunitas, atau bahkan beberapa kelompok, beberapa institusi, beberapa komunitas yang kemudian disebut multiple cases (Gillham dalam Kamayanti, 2016 : 76). Sifat dari pendekatan studi kasus ini adalah kontekstual. Kontekstual mengacu pada fokus studi kasus yang sangat berhubungan atau bergantung pada situasi dan kondisi pada tempat tertentu.

Studi kasus bukan hanya sekedar wawancara, dokumentasi, dan observasi, akan tetapi penting bagi peneliti untuk melakukan treatment tertentu terhadap kumpulan data tersebut. Pendekatan studi kasus dapat dibagi menjadi lima jenis. Dalam penelitian ini jenis studi kasus yang digunakan adalah diciplined comparative. Kamayanti (2016 : 77) menyebutkan bahwa definisi pendekatn studi kasus jenis ini sebagai strategi yang digunakan oleh peneliti untuk memperoleh pemahaman mengenai perbandingan antara kasus/praktik yang sedang dipelajari dengan teori yang mapan. Studi kasus jenis ini, akan bersifat normatif. Pendekatan studi kasus diciplined comparative digunakan dalam penelitian ini dengan pertimbangan tujuan penelitian yang berusaha untuk memahami dan mempelajari praktik permodalan pada UKM Sarung Tenun ATBM di desa Wedani kecamatan Cerme Kabupaten Gresik.

\section{Unit Analisis}

Penelitian kualitatif tidak mengutamakan besarnya populasi atau jumlah sampel. Aspek yang lebih ditekankan dalam penelitian kualitatif adalah persoalan kedalaman (kualitas) dan bukan banyaknya (kuantitas) data (Rachmat, 2006;58). Untuk dapat memahami suatu fenomena yang terjadi diperlukan unit analisis atau fokus pengamatan.

Hamidi (2005;75-76) menyatakan bahwa unit analisis adalah satuan yang diteliti yang bisa berupa individu, kelompok, benda atau suatu latar peristiwa sosial seperti misalnya aktivitas individu atau kelompok sebagai subjek penelitian. Unit analisis dalam penelitian ini adalah persepsi, sikap, pengalaman, dan kebiasaan informan dalam hal ini pengusaha atau pemilik UKM Sarung Tenun ATBM yang berkaitan dengan aspek permodalan. Penentuan unit analisis yang telah disebutkan bertujuan untuk mengungkap praktik permodalan bagi 
UKM Sarung Tenun di Desa Wedani Kecamatan Cerme.

\section{Informan dan Lokasi Penelitian}

Informan adalah salah satu subjek yang sangat berperan dalam penelitian kualitatif. Kriteria informan yang dipilih dalam penelitian ini adalah mereka yang menjadi pelaku dalam suatu fenomena. Selain itu, penentuan informan dalam penelitian ini juga didasarkan pada pengalaman langsung informan terkait dengan fenomena yang akan diteliti. Kriteria tersebut ditetapkan dengan tujuan untuk mengungkap makna dari suatu fenomena secara alamiah. Dalam penelitian ini informannya adalah 4 (empat)3 (tiga) pemilik (owner) UKM dan kepalabagian Ekonomi Pembangunan di DesaWedani.

Lokasi yang diambil sebagai tempat penelitian adalah daerah Kabupaten Gresik. Penelitian ini secara spesifik dilakukan di desa Wedani Kecamatan Cerme Kabupaten Gresik tepatnya pada industri UMKM Sarung Tenun ATBM. Alasan yang mendasari lokasi penelitian adalah kemudahan dalam pengumpulan data. Selain itu, penentuan lokasi penelitian tersebut didasarkan pada adanya fenomena sebagian UMKM yang gulung tikar dan sebagian lain yang masih bertahan karena masalah permodalan yang membuat peneliti tertarik untuk meneliti objek tersebut.

\section{Teknik Penggalian Data}

Teknik pengumpulan data merupakan langkah yang penting dalam melakukan penelitian, karena penelitian bertujuan untuk mengumpulkan data, dan mengolahnya untuk diberikan justifikasi. Pengambilan data dapat dilakukan dalam berbagai setting, berbagai sumber dan berbagai cara. Dalam penelitian kualitatif, pengambilan data dilakukan pada natural setting (kondisi yang alamiah). Teknik pengumpulan data yang akan dilakukan oleh peneliti adalah wawancara dan dokumentasi.

\section{Wawancara.}

Wawancara adalah percakapan dengan maksud tertentu. Percakapan itu dilakukan oleh dua pihak, yaitu pewawancara (interviewer) yang mengajukan pertanyaan dan terwawancara (interviewee) yang memberikan jawaban atas pertanyaan itu (Moeloeng, 2014:186).

\section{Dokumentasi}

Studi dokumentasi merupakan salah satu cara yang dapat dilakukan peneliti kualitatif untuk mendapatkan gambaran dari sudut pandang subjek melalui suatu media tertulis dan dokumen lainnya yang ditulis atau dibuat langsung oleh subjek yang bersangkutan (Herdiansyah, 2014;143). Kemudian menurut Sugiyono $(2013 ; 240)$ studi dokumen merupakan pelengkap dari penggunaan metode observasi dan wawancara dalam penelitian kualitatif.

\section{Teknik Pengorganisasian Data}

Dalam penelitian kualitatif, data diperoleh dari berbagai sumber, dengan menggunakan teknik pengumpulan data yang bermacam-macam dan dilakukan secara terus menerus sampai datanya jenuh. Miles dan Huberman dalam Herdiansyah (2010) mengatakan bahwa analisis data paling serius dan sulit dalam analisis data kualitatif. Ini dapat disebabkan karena metode analisis belum dirumuskan dengan baik.

Herdiansyah (2010) mengemukakan beberapa poin penting yang perlu diperhatikan dalam melakukan analisis data kualitatif, antara lain :

1. Analisis data kualitatif dapat dilakukan secara simultan dengan proses pengumpulan data, interpretasi data dan penulisan naratif lainnya.

2. Pastikan bahwa proses analisis data kualitatif yang telah dilakukan berdasarkan pada proses reduksi data (data reduction) dan interpretasi (interpretation).

3. Ubah data hasil reduksi ke dalam bentuk matriks.

4. Identifikasi prosedur pengodean (coding) digunakan dalam mereduksi informasi ke dalam tema- tema atau kategori-kategori yang ada.

5. Hasil analisis data yang telah melewati proses reduksi yang telah diubah menjadi 
bentuk matriks diberi kode (coding), selanjutnya disesuaikan dengan model kualitatif yang dipilih.

\section{Teknik Analisis Data}

Dalam penelitian kualitatif, data diperoleh dari berbagai sumber, dengan menggunakan teknik pengumpulan data yang bermacam-macam dan dilakukan secara terus menerus sampai datanya jenuh. Miles dan Huberman dalam Herdiansyah (2010) mengatakan bahwa analisis data paling serius dan sulit dalam analisis data kualitatif. Ini dapat disebabkan karena metode analisis belum dirumuskan dengan baik.

Herdiansyah (2010) mengemukakan beberapa poin penting yang perlu diperhatikan dalam melakukan analisis data kualitatif, antara lain :

1. Analisis data kualitatif dapat dilakukan secara simultan dengan proses pengumpulan data, interpretasi data dan penulisan naratif lainnya.

2. Pastikan bahwa proses analisis data kualitatif yang telah dilakukan berdasarkan pada proses reduksi data (data reduction) dan interpretasi (interpretation).

3. Ubah data hasil reduksi ke dalam bentuk matriks.

4. Identifikasi prosedur pengodean (coding) digunakan dalam mereduksi informasi ke dalam tema- tema atau kategori-kategori yang ada.

5. Hasil analisis data yang telah melewati proses reduksi yang telah diubah menjadi bentuk matriks diberi kode (coding), selanjutnya disesuaikan dengan model kualitatif yang dipilih.

Analisis yang dilakukan adalah bertujuan untuk mendeskripsikan praktik permodalan pada UMKM Sarung Tenun ATBM. Peneliti mengacu pada teknik analisis data model interaktif menurut Miles dan Haberman dalam Herdiansyah (2010) terdiri atas empat tahapan yang dilakukan, yaitu :

1. Pengumpulan data
Pada awal penelitian, peneliti melakukan studi pre-eliminary berupa penelitian awal yang menemukan fenomena bahwa beberapa pelaku UKM melakukan pinjaman ke bank sebagai langkah pemenuhan kebutuhan modal usahanya. Studi ini berfungsi untuk verifikasi dan pembuktian awal bahwa fenomena yang diteliti itu benar-benar ada.

2. Reduksi data

Inti dari reduksi data adalah proses penggabungan dan penyeragaman segala bentuk data yang diperoleh menjadi satu bentuk tulisan (script) yang akan dianalisis. Hasil wawancara yang dilakukan peneliti dengan informan (pelaku UKM dan/atau bagian keuangan UKM) akan diformat menjadi bentuk verbatin wawancara. Hasil observasi dengan menggunakan metode Anecdotal Record dan Behavioral Checklist diformat menjadi tabel hasil observasi disesuaikan dengan metode observasi tersebut. Hasil studi dokumentasi dengan menggunakan dokumen resmi laporan keuangan usaha UMKM periode tahun 2014 diformat menjadi skrip analisis dokumen.

3. Display Data

Setelah semua data telah diformat berdasarkan instrumen pengumpulan data dan telah dibentuk dalam tulisan, langkah selanjutnya adalah melakukan display data. Tahap display data yaitu menentukan kategori tema, subkategori tema dan proses pengodean.

4. Kesimpulan/Verifikasi

Setelah melakukan tiga tahapan dalam menganalisis data, peneliti mengevaluasi hasil dari pengamatan dan wawancara serta data yang didapat, membandingkan teoriteori dengan hasil pengamatan dan mengevaluasi bagaimana makna pelaporan modal dalam perspektif budaya bagi pelaku UKM.

\section{Kredibilitas Penelitian}

Berbeda dengan penelitian nonkualitatif dengan paradigma ilmiah, penelitian kualitatif dengan 
paradigma alamiah mempunyai khasanah tersendiri mengenai keabsahan atas data penelitian yang dikumpulkan. Penelitian kualitatif lebih bersifat subjektif apabila dibandingkan dengan penelitian nonkualitatif. Menurut Moleong (1988 : 324) ada empat kriteria keabsahan data dalam penelitian kualitatif. Empat kriteria tersebut adalah kredibilitas (credibility), keteralihan (transferability), kebergantungan (dependenability), dan kepastian (confirmability). Cara yang digunakan untuk menguji keabsahan data disebut teknik pemeriksaan keabsahan data. Terdapat banyak cara untuk menguji keabsahan data penelitian kualitatif.

Dalam penelitian ini, teknik trianggulasi digunakan sebagai teknik pemeriksaan keabsahan data. Alasan peneliti menggunakan trianggulasi sebagai teknik pemeriksaan keabsahan data didasarkan pada beberapa pertimbangan. Pertama, ruang lingkup objek penelitian. Penelitian ini melibatkan peneliti sebagai alat untuk mengumpulkan data dengan cara melakukan dialog intersubjektivitas dengan informan. Untuk menguji keabsahan data yang disampaikan informan, peneliti perlu mengumpulkan data tambahan. Data tersebut misalnya berupa dokumen terkait, ataupun hasil pengamatan lapangan lainnya. Peneliti perlu membandingkan data hasil wawancara dengan data lainnya (trianggulasi sumber). Yang kedua, peneliti perlu mengadakan pengecekan data dengan peneliti lainnya, dalam hal ini adalah pembimbing penelitian. Selain kedua alasan tersebut, pendasaran logis atas pemilihan trianggulasi sebagai teknik pemeriksaan keabsahan data adalah cakupan dari trianggulasi itu sendiri. Menurut peneliti, trianggulasi dapat mencakup teknik pemeriksaan keabsahan data lainnya.

Sesuai dengan yang dikatakan Moleong (2014 : 332), trianggulasi merupakan cara terbaik untuk menghilangkan perbedaan konstruksi kenyataan yang ada dalam konteks suatu studi sewaktu mengumpulkan data tentang berbagai kejadian dan hubungan dari berbagai pandangan.

\section{HASIL DAN PEMBAHASAN}

Semua informan dalam penelitian ini tidak ada yang merasa keberatan untuk di sebutkan namanya, adapun informan penelitian ini adalah:

1. Bapak Bambang Supeno

Bapak Bambang Supeno adalah kepala bagian Ekonomi Pembangunan yang ada di Desa Wedani. Bapak Bambang Supeno merupakan informan pertama yang peneliti wawancara. Beliau sangat antusias untuk memberikan informasi yang peneliti butuhkan kapan saja asalkan tidak menganggu beliau dalam bekerja. Beliau menjelaskan bagaimana sarung tenun ini berdiri dan mejelaskan keadaan UKM sarung tenun di Desa Wedani. Pada awalnya sarug tenun ini 2011 Sarung tenun mencapai kejayaan pada tahun 2009 dan mengalami penurunan pada tahun 2014 sampai sekarang.

Beliau menjelaskan bahwa usaha sarung tenun ini sangat membantu perekonomian masyarakat Desa Wedan. Hampir semua masyarakan di Wedani mata pencahariannya adalah sarung tenun, sampai-sampai tenaga kerja banyak di datangkan dari luar Desa Wedani bahkan luar kota seperti dari lamongan dan bojonegoro. Dengan senang hati beliau bersedia menjawab semua pertanyaan yang diajukan peneliti. Beliau pun tidak segan-segan untuk membantu peneliti mencarikan informan lainnya agar bersedia menjadi informan dalam penelitian serta mencarikan data-data yang berguna bagi kesempurnaan penelitian ini.

2. Bapak Hj Tasripin

Informan kedua adalah Bapak $\mathrm{Hj}$ Tasripin beliau merupakan pemilik usaha sarungtenun di Desa Wedani. Usaha sarung tersebut mulai dirintis oleh Bapak Hj Tasripin sejak tahun 1978 dan berkembang hingga sekarang. Informan juga menjelaskan bahwa ia mendirikan usaha sarung karena memiliki latar belakang di bidang tersebut. Pemahaman beliau terhadap bisnis sarung didapatkan ketika beliau masih bersekolah tingkat SMP, dimana orang tua Bapak $\mathrm{Hj}$ Tasripin merupakan buruh yang bekerja pada 
juragan sarung kenaamaan di desa setempat. Kemudian setelah orang tuanya meninggal, maka beliau mencoba untuk membuka usaha sarung dengan skala kecil, dengan menjualnya pada produsen besar, atau dengan bekerja menjadi penjasa maklon, yakni menerima order dari produsen besar untuk sarung motif tertentu.

Namun seiring berkembangnya bisnis yang dikelola oleh Bapak $\mathrm{Hj}$ Tasripin, beliau tidak lagi memenuhi pesanan dari produsen besar, namun langsung menjual ke pengecer ataupun toko yang ada di Surabaya ataupun Gresik. Jumlah karyawan yang dimiliki oleh Bapak Hj Tasripin adalah 19 orang yang terdiri dari 10 orang wanita dan 9 pria. Kemudian, omzet dari usaha sarung Bapak Hj Tasripin adalah Rp. 15.000.000 per bulannya.

3. Bapak Abdullah

Informan ketiga adalah Bapak Abdullah yakni pemilik usaha sarung tenun yang sudah berjalan sejak tahun 1992. Menurut keterangan informan ketiga modal untuk membuka usaha tersebut berasal dari hasil penjualan tanah. Kemudian seteleh peneliti mencoba mengajukan pertanyaan mengapa beliaumemilih membuka usaha sarung, maka beliau menjawab bahwa sarung tenun khas Cerme memiliki keunikan tersendiri dari coraknya yang berbeda dengan sarung yang telah beredar di pasaran. Kemudian menurut beliau permintaan sarung khas Cerme ini cukup menjanjikan terutama pada momentum Bulan Ramadhan, Bulan Haji, dan momen peringatan hari besar Islam lainnya.

Jumlah karyawan yang dimiliki oleh Bapak Abdullah berjumlah 27 orang, dan di dominasi oleh pekerja wanita dengan jumlah 19 orang. Adapun tugas utama dari pekerja wanita adalah menenun dengan bantuan alat ATBM (alat tenun bukan mesin) serta pekerjaan lainnya yakni pengepakan, sedangkan pekerja laki-laki melakukan pekerjaan lain seperti membeli bahan, pewarnaan, hingga pengiriman. Adapun omzet dari usaha yang dijalankan oleh Bapak
Abdullah adalah Rp. 10.000 .000 per
bulannya.

4. Ibu Sutik

Informan keempat adalah Ibu Sutik yang memiliki usaha sarung sarung tenun yang berdiri sejak tahun 2000 dengan modal awal yang berasal dari pesangon. Ibu Sutik membuka usaha sarung setelah beliau di PHK oleh perusahaan tempat beliau bekerja. Adapun jumlah tenaga kerja yang dimiliki Ibu Sutik sebanyak 8 orang dengan 3 orang pekerja laki-laki dan 4 orang pekerja perempuan. Omzet yang dihasilkan oleh Ibu Sutik adalah Rp 5.000.000 s/d Rp 8.000.000 per bulan.

\section{Deskripsi Hasil Kronologi Penelitian}

Berdasarkan hasil pengamatan serta keterangan informan, diketahui bahwa informan kedua, ketiga dan keempat. Informan kedua dalam penelitian ini, menggunakan modal sendiri yang berasal dari tabungan si pemilik saat mulai menjalankan usahanya. Lebih lanjut informan kedua juga mnejlaskan, " $Y a$ dapet dari nabung mbak, ngumpulno engga titik, oleh teko dodolan tak celengi".

Usaha sarung yang dijalankan oleh Bapak Hj Tasripin mulai berdiri tahun 1978 dan telah berjalan serta terus berkembang hingga sekarang. Informan kedua juga menjelaskan bahwa usahanya dimulai ketika ia berhasil mengumpulkan modal dari hasil penjualan sarungnya. Beliau mengaku mendapatkan ilmu pembuatan sarung dari orang tuanya, ketika beliau masih menempuh pendidikan tingkat SMP, orang tuanya telah bekerja sebagai buruh pembuat sarung di produsen besar di desa setempat. Sepeninggal orang tuanya, beliau mencoba membuat sendiri sarung tenun dengan modal yang sangat terbatas dan kemudian menjualnya pada produsen besar tersebut, tak jarang pada awal merintis usahanya beliau juga menerima pesanan dari produsen besar untuk motif tertentu. Namun setelah usahanya mulai stabil, beliau melakukan penjualan langsung kepada pengecer ataupun toko yang ada di Gresik ataupun Surabaya. 
Informan kedua menjelaskan bahwa penggunaan modal sendiri ketika mulai membuka usaha dilakukan karena menurut beliau terlalu berisiko jika menjalankan usaha yang sifatnya musiman dengan bantuan sumber dana ekternal (hutang). "Jadi ngene mbak, saya kan wong deso ya, nah nek wong desogawe sawah, wani mbak ngapek utangan, tapi nek gawe usaha ngene iki, yo wedi, kan ramene pas bulan tertentu" ungkap Bapak Hj Tasripin.

Informan ketiga, Bapak Abdullah pemilik usaha sarung tenun yang berdiri sejak tahun 1992 . informan juga menjelaskan bahwa pada saat awal menjalankan usahanya, modal diperoleh dari hasil penjualan tanah, kemudian usaha tersebut terus berkembang hingga sekarang. Baik informan pertama maupun informan kedua memiliki kesamaan dari sisi modal awal yang digunakan. Kedua informan sama-sama menggunakan modal sendiri pada saat awal menjalankan usaha. Menurut keterangan informan kedua, Bapak Abdullah alasan beliau hanya menggunakan modal yang berasal dari penjualan tanah karena beliau merasa terlalu sulit untuk megajukan kredit usaha kepada bank. "Mbulet mbak" tukasnya, "Yaoop yo mbak, soale kan lagek mbuka usahae, kan nek kredit bank iku syarate harus wes jalan usahae, lha awak dewe lagek buka" jelas "Bapak Abdullah". Berdasarkan ungkapan informan tersebut, maka diketahui bahwa informan memiliki pandangan bahwa jika usaha belum berjalan (pada tahap awal) akan cenderung sulit untuk menggunakan alternatif permodalan eksternal dari lembaga keuangan seperti bank dan sejenisnya.

Informan keempat, yaitu Ibu sutik Informan menjelaskan bahwa usahanya dimulai pada tahun 2000 setelah beliau di PHK sepihak dari perusahaannya. Adapun modal awal dalam menjalakan usahanya diperoleh dari uang pesangon dari perusahaan. informan ketiga menjelaskan bahwa sebenarnya ia tidak ada niat untuk menjadi wirausahawan, namun keadaan yang memaksa. Ibu Sutik menjelaskan bahwa ia di PHK secara sepihak oleh perusahaan tempat ia bekerja karena ia menderita sakit selama lebih dari 3 bulan, yang mengharuskan ia beristirahat total, sehingga perusahaan mengambil kebijakan dengan memberhentikan dirinya. "Yo dilereni mbak mergane aku loro gak iso kerjo 3 bulan lebih, tapi Alhamdulillah kok yo oleh pesangon mbak, lah iku tak gawe bondo".

\section{Tema}

Pada UKM Sarung Tenun desa Wedani dalam permodalan yang diterapkan oleh ketiga informan dalam penelitian ini telah cukup banyak membantu perkembangan usaha yang mereka jalankan. Diketahui pada masa awal usaha dijalankan ketiga pengusaha sarung tenun lebih memilih untuk menghindari penggunaan modal eksternal dari bank dan lebih memilih untuk menggunakan modal sendiri baik itu berasal dari tabungan pribadi informan kedua ataupun dana lainnya seperti penjualan tanah informan ketiga, serta uang pesangon informan keempat.Hal tersebut sesuai dengan pernyataan Nugroho (2014) bahwa sumber pendanaan berasal dari modal sendiri dan modal pinjaman, dana tersebut dapat digunakan untuk melakukan kegiatan investasi .

\section{Konstekstual}

Ketika dihadapkan pada situasi lonjakan permintaan yang signifikan namun modal yang dimiliki tidak mencukupi untuk memenuhi permintaan tersebut. Cara pandang setiap informan berbeda, Informan kedua lebih cenderung untuk mengambil kebijakan penetapan uang muka yang tinggi dari pelanggannya. Menurut informan kedua, uang muka (DP) yang tinggi itu ia gunakan untuk membeli bahan secara kredit dari para suplier. Sehingga dapat disimpulkan bahwa Bapak $\mathrm{Hj}$ Tasripin tidak memprioritaskan hutang bank sebagai alternatif sumber modal dalam menghadapi kebutuhan dana yang mendesak.

Sedangkan informan ketiga memiliki pandangan bahwa penggunaan hutang dari lembaga keuangan seperti bank dan sejenisnya relatif mudah karena berdasarkan pengalaman beliau saat mulai merintis usaha, jika modal yang beliau miliki tidak dapat memnuhi kewajiban jangka pendek. Pihak bank enggan untuk 
memberi kredit karena usahanya balum berjalan. Kemudian, informan ketiga juga beranggapan bahwa hutang bank relatif aman ketika dilakukan saat usaha sudah berjalan beberapa tahun, karena dalam pandangan beliau, jika usaha sudah berjalan beberapa tahun, maka kemampuan untuk memenuhi kewajiban jangka pendek (likuiditas) dirasa cukup baik.

Informan memandang bahwa pengajuan pinjaman kepada kerabat relatif lebih mudah, dan tidak kompleks seperti halnya pada bank atau lembaga keuangan lainnya. Tetapi ibu surtik memilih sember dana yang beliau dapatkan dari pinjaman keluarga atau kerabat. Kemudian, informan juga menambahkan bahwa jika di suatu hari terjadi kesulitan dalam pembayaran, maka akan dapat diselesaikan secara kekeluargaan. Ibu Sutik juga memandang penggunaan hutang bank sebagai beban bagi kelangsungan usaha yang ia jalankan.

\section{Verifikasi}

Ketika dihadapkan pada situasi lonjakan permintaan yang signifikan namun modal yang dimiliki tidak mencukupi untuk memenuhi permintaan tersebut para pemilik usaha memiliki langkah yang berbeda namun pada akhirnya para pelaku usaha tidak menggunakan dana eksternal seperti bank karena bunga bank yang tinggi di samping susahnya akses bagi para pelaku usaha untuk dapat pinjaman dari bank. Para pengusaha sarung tenun di Desa Wedani memlih mengambil uang muka yang banyak dari konsumen, dan memiih untuk mempergunakan uang tabungan untuk memenuhi kebutuhan jangka pendek.

\section{Display Data}

Dari kesimpuan di atas dapat di ketahui bahwa pengunaan hutang pada bank mempunyai resiko bagi kelangsungan usaha sarung tenun di Desa Wedani. Penggunaaan modal yang baik dan efesien di terapkan para pelaku usaha sarung tenun untuk memenuhi kebutuhan usahanya, hal ini berpengaruh terhadap pendapatan. Struktur modal yang optimal adalah struktur modal yang mengoptimalkan keseimbangan antara resiko dan pengembalian. Pelaku usaha mengeluarkan modal dalam kegiatan usaha adalah untuk mendapatkan ROE. ROE atau yang disebut kemampuan perusahaan dalam menghasilkan laba bersih dengan modal sendiri dalam kegiatan berwirausaha seperti halnya UKM sarung tenun di Wedani dalam hal hubungan antara modal dan ROE yaitu semakin tinggi retrun on equity ROE maka semakin bagus karena perolehan laba yang dihasilkan oleh perusahaan tersebut akan semakin besar, begitu pula sebaliknya semakin rendah retrun on equity ROE mengarah pada angka negative maka prusahaan tersebut akan mengalami kerugian. Dan ketika para pengusaha di hadapkan pada permintaan yang tinggi para pengusaha memilih menggunakan kas untuk memenuhi kebutuhan jangka pendeknya. Modalpada UKM sarung tenun di dorong atau di perkuat oleh adanya kas.Kedudukan kas di antara hubungan modal dan ROE adalah untuk membiayai operasioanal usaha.

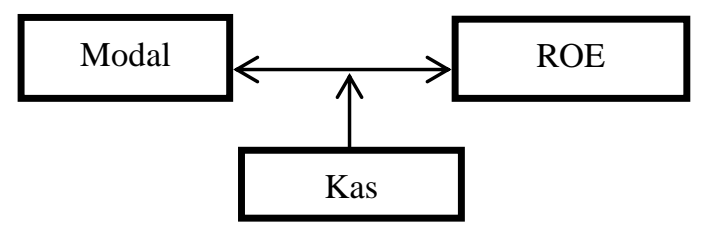

Gambar 4: Display Analisis Data

\section{SIMPULAN}

Berdasarkanhasil penelitian dan pembahasan tersebut, peneliti mengambil kesimpulan tentang permodalan di UKM sarung tenun Desa Wedani Kecamatan Cerme:

1. Modal sendiri berpengaruh dengan tingkat pengembalian modal.

2. Modal sendiri (equity) berhubungan dengan tingkat pengembalian modal sendiri yang di perkuat dengan kas (liquiditas).

Berdasarkan hasil penelitian di UKM sarung tenun di Desa Wedani Kecamatan Cerme, peneliti memberikan saran yang bermaksud untuk meningkatkan dan mengembangkan usaha pada usaha sarung tenun, beberapa saran yang dapat diberikan peneliti diantaranya adalah:

\section{Bagi UKM}

Diharapkan dapat mengelola usahanya dengan optimal dan dalam meningkatkan 
laba pelaku usaha perlu memperhatikan modal yang di gunakan dan kas untuk alokasi dana guna investasi.Modal pada UKM Desa Wedani mayoritas menggunakan modal sendiri. Untuk memaksimalkan modal usaha pelaku UKM sarung tenun Desa Wedani bisa melakukan pinjaman keluar seperti bank, BPR dan lain - lain. Dalam penggunaan Modal external seperti pinjaman dari bank juga bermanfaat untuk keberlangsunganusaha sarung tenun adapun manfaat pinjaman modal dari bank yaitu pihak bank bisa membantu pelaku usaha dalam mengembangkan usahanya menjadi lebih besar dan sukses dalam berbisnis, pelaku usaha juga memiliki rasa nyaman terhadap bank dengan sistem dan persyaratan yang jelas dalam melakukan proses hutang piutang. Dalam pembayaran piutang yang dilakukan oleh pelaku usaha terhadap pihak bank bisa dilakukan dengan di angsur beberapa kali sesuai kesepakatan bersama.

2. Bagi peneliti selanjutnya

Untuk menguji hubungan modal sendiri, perputaran kasdan retrun On Equity ROE dengan studi fenomonologi karena untuk

\section{DAFTAR PUSTAKA}

Afifah, R.Z. \& Setiawan, A.H. 2012.Analisis Bantuan Modal dan Kredit Bagi Kelompok Pelaku Usaha Mikro Oleh Dinas Koperasi dan UMKM Kota Semarang (Studi Kasus: KPUM di Kelurahan Pekunden, Kecamatan Semarang Tengah)(Doctoral dissertation, Fakultas Ekonomika dan Bisnis).

Barlian, I., Gomulia, B. \& Maria, E. 2013. Peranan Modal Dari Keluarga Pada 3 UKM di Bandung. Research ReportHumanities and Social Science, 1.

Herdiansyah, H. 2010. Metodologi Penelitian Kualitatif : untuk ilmu-ilmu sosial. Jakarta : Salemba Empat.

Kriyantono, R. \& Rakhmat, S.J. 2006. Metode Penelitian Komunikasi.

Lexy, J., Moleong. 2014. Metode Penelitian Kualitatif.
Moleong, J., Lexy. 1988. Metode Penelitian Kualitatif. Bandung: PT Remaja Rosdakarya.

Muthmainah, Dinda Audrienne. 2016. Kontribusi UMKM Terhadap PDB Tembus Lebih Dari 60 Persen. http://www.cnnindonesia.com. Diakses pada tanggal 20 Maret 2017.

Nadjikh, Mokhammad. 2015. Pasar Rakyat Gresik, Ajang Kreatif Cari UKM Berjiwa Petarung. http://www.kabarbisnis.com. Diakses pada tanggal 20 Maret 2017.

Nugroho, N.C. 2014. Analisis Pengaruh Profitabilitas, Pertumbuhan Penjualan, Ukuran Perusahaan, dan Umur Perusahaan Terhadap Struktur Modal Usaha Mikro Kecil dan Menengah Kerajinan Kuningan Di Kabupaten Pati.Management Analysis Journal, 3(2).

Sugiyono,2013, Metode Penelitian Kuantitatif dan Kualitatif dan $R \& D$, Alfabeta, Bandung

Saraswati, B.D., Fevriera, S. \& Dwijayanti, S. 2011. Sumber Pembiayaan Pedagang di Salatiga.

Sriyana, J. 2010. Strategi Pengembangan Usaha Kecil dan Menengah (UKM): Studi Kasus di Kabupaten Bantul.Simposium Nasional, pp.79-103.

Sukoco, A.R.F. 2015. Pengelolaan Modal Kerja Usaha Mikro Untuk Memperoleh Profitabilitas (Studi Pada Ud. Warna Jaya Periode 2011-2013).Jurnal Administrasi Bisnis, 22(1).

Warsono, M.M. 2003. Manajemen Keuangan Perusahaan.Jilid Satu, Edisi Tiga, Cetakan Pertama, Bayumedia Publishing, Malang.

Weston, F., J,. dan Brigham, F. Eugene. 2013. Manajemen Keuangan, Edisi Ketujuh, Jilid Dua.

Van Horne, J.C. \& Wachowicz Jr, J.M., 2002. Prinsip-pronsip Manajemen Keuangan Edisi Kesembilan, DiIndonesiakan oleh Heru Sutojo.

Nuswandari, Cahyani. 2013. Determinan Struktur Modal dalam Prespektif Pecking Order Theory dan Agency heory.JurnalAkuntansi. 